J. Asiat. Soc. Bangladesh, Sci. 39(2): 231-238, December 2013

\title{
COPPER, CADMIUM, CHROMIUM AND LEAD BIOACCUMULATION IN STINGING CATFISH, HETEROPNEUSTES FOSSILIS (BLOCH) AND FRESHWATER MUSSEL, LAMELLIDENS CORRIANUS LIA AND TO COMPARE THEIR CONCENTRATION IN SEDIMENTS AND WATER OF TURAG RIVER
}

\author{
SUMAN MANDAL ${ }^{1}$ AND ABU TWEB ABU AHMED \\ Department of Zoology, University of Dhaka, Dhaka-1000, Bangladesh
}

\begin{abstract}
The present study was carried out to determine the level of bioaccumulation of some heavy metals namely Copper $(\mathrm{Cu})$, Cadmium $(\mathrm{Cd})$, Chromium $(\mathrm{Cr})$ and Lead $(\mathrm{Pb})$ in freshwater fish Stinging catfish (Heteropneustes fossilis Bloch, 1794) and freshwater Mussel (Lamellidens corrianus Lia, 1834) collected from Turag river during the months of October to December 2010. The accumulation levels were then compared with the concentration levels of sediments and water of the same river. In H. fossilis the average bioaccumulations were $\mathrm{Cu} 13.27 \pm 2.47 \mathrm{mg} / \mathrm{kg}$; $\mathrm{Cd} 0.215 \pm 0.208 \mathrm{mg} / \mathrm{kg}$; $\mathrm{Cr} 1.46 \pm$ $0.431 \mathrm{mg} / \mathrm{kg}$ and $\mathrm{Pb} 0 \mathrm{mg} / \mathrm{kg}$ in dry weight while $\mathrm{Cu} 31.90 \pm 6.202 \mathrm{mg} / \mathrm{kg} ; \mathrm{Cd} 0.182 \pm$ $0.025 \mathrm{mg} / \mathrm{kg}$; Cr $0.0367 \pm 0.039 \mathrm{mg} / \mathrm{kg}$ and $\mathrm{Pb} 3.865 \pm 1.041 \mathrm{mg} / \mathrm{kg}$ in dry weight of $L$. corrianus. Average concentration of metals in sediments of Turag river were $\mathrm{Cu} 54.95 \pm$ $9.218 \mathrm{mg} / \mathrm{kg} ; \mathrm{Cd} 0.05 \pm 0.011 \mathrm{mg} / \mathrm{kg} ; \mathrm{Cr} 5.575 \pm 0.608 \mathrm{mg} / \mathrm{kg}$ and $\mathrm{Pb} 34.89 \pm 5.554$ $\mathrm{mg} / \mathrm{kg}$ in dry weight and in water these levels were $\mathrm{Cu} 0.0253 \pm 0.024 \mathrm{ppm} ; \mathrm{Cd} 0.0012 \pm$ $0.001 \mathrm{ppm} ; \mathrm{Cr} 0.2335 \pm 0.044 \mathrm{ppm}$ and $\mathrm{Pb} 0.1169 \pm 0.041 \mathrm{ppm}$. The bioaccumulation level of heavy metals in Turag river were higher than the FAO approved standard level.
\end{abstract}

Key words: Bioaccumulation, Heavy metal, Heteropneustes fossilis, Lamellidens corrianus, Turag river

\section{Introduction}

Heavy metals are the metallic elements of high atomic weight which would mainly include the transition metals, some metalloids, lanthanides, and actinides. Many different definitions have been proposed on the basis of density, atomic number, atomic weight as well as their chemical properties or toxicity. Moreover, the term heavy metal has been called a "misinterpretation" in an IUPAC technical report due to its contradictory definitions and lack of a "coherent scientific basis". Thus, an alternative term toxic metal has been proposed, but no consensus of exact definition exists either (Davies et al. 2006). These are natural components of the Earth's crust and cannot be degraded or destroyed. A small extent of these may enter our body via food, drinking water and inhalation of contaminated air. As a result, gradual concentration of higher level leads to poisoning (Bendicho and Lavilla 2003). The thing is more acute in aquatic ecosystems,

${ }^{1}$ Corresponding author: E-mail: suman.magician@yahoo.com 
where the industrial and municipal wastes as well as the soil deposited forms are constantly being washed out by the normal and acid rain waters into the nearby waterbodies and therein bioaccumulate in the body of all kinds of aquatic organisms. In small amounts, trace or heavy metals are normal constituents of aquatic organisms but at higher concentrations, they exert ranges of toxic effects that are metabolic, physiologic, behavioral and ecological in nature (Kebede and Wondimu 2004). The sources are then transmitted those and even some essential trace elements in human body through food chain can cause damage to health or even death at increasing concentrations. The form in which an element is ingested also plays a major role in its restorability or toxicity.

Besides, heavy metal pollution may also arise from many other sources, but most common sources are the purification of metals, e.g., the smelting of copper and the preparation of nuclear fuels. Electroplating is the primary source of chromium and cadmium. Through precipitation of their compounds or by ion exchange into soils and mud, heavy metal pollutants can localize and lay dormant. Unlike organic pollutants, heavy metals do not decay and thus pose a different kind of challenge for remediation.

Some of these elements (cobalt, copper, chromium, manganese, nickel) are necessary for human in minute amounts while others are carcinogenic or toxic. Manganese, mercury, lead and arsenic are harmful to the central nervous system. Mercury, lead, cadmium and copper are carcinogenic to the kidneys and liver. Similarly, nickel, cadmium, copper and chromium are harmful to the skin, bones, or teeth (Bhattacharya et al. 2007).

Copper is an essential substance to human life, but in high doses it can cause anemia, liver and kidney damage, and stomach and intestinal irritation. Similarly, long-term exposure of cadmium is associated with renal disfunction. High exposure can lead to obstructive lung disease and has been linked to lung cancer, although data concerning the latter are difficult to interpret due to compounding factors. Cadmium may also produce bone defects (osteomalacia, osteoporosis) in humans and animals. Low-level of chromium exposure can irritate the skin and cause ulceration. Long-term exposure can cause kidney and liver damage, and damage too the circulatory and nerve tissues. Chromium often accumulates in aquatic life, adding to the danger of eating fish that may have been exposed to high levels of chromium. In humans exposure to lead can result in a wide range of biological effects depending on the level and duration of exposure. Various effects occur over a broad range of doses, with the developing foetus and infant being more sensitive than the adult. High levels of exposure may result in toxic biochemical effects in humans which in turn causes problem in the synthesis of haemoglobin, effects on the kidneys, gastrointestinal tract, joints and reproductive system, and acute or chronic damage to the nervous system. (Lenntech 2010).

Contaminations of aquatic ecosystems with trace elements received great attention since the events of $\mathrm{Hg}$ and $\mathrm{Cd}$ poisoning through fish and shellfish in Minamata, Japan. In recent years, there has been an increasing interest in the utilization of fishes as bio- 
indicators of the integrity of aquatic environmental systems. Turag and Buriganga rivers encircled the major part of Dhaka city and thereby highly polluted with municipal and industrial wastes. Local people use its water for many of their daily activities and fishes for consumption. Considering all these things, the main objectives of this research were to determine the contamination levels of heavy metals in sediments and water as well bioaccumulation in aquatic organisms like fish and mollusks.

\section{Materials and Methods}

Freshwater Stinging catfish or Shing, Heteropneustes fossilis (Bloch, 1794) and freshwater mussel, Lamellidens corrianus Lia, 1834 as well as sediment and water samples were collected from Turag river at Diabari to Chatbari region $\left(23^{0} 47^{\prime} 59.45^{\prime \prime} \mathrm{N}\right.$ $23^{\circ} 49^{\prime} 44.29^{\prime \prime} \mathrm{N}$ and $\left.90^{\circ} 20^{\prime} 35.10^{\prime \prime} \mathrm{E}-90^{\circ} 20^{\prime} 32.82^{\prime \prime} \mathrm{E}\right)$ during the months of October to December, 2010. Samples were prepared step by step according to recommended procedures by AOAC (AOAC International 2002). Sediment, water, fishes and mussels were separately digested by nitric acid $\left(\mathrm{HNO}_{3}\right)$ and perchloric acid $\left(\mathrm{HClO}_{4}\right)$ in a hot plate apperatus. The present work was completed by Flame Atomic Absorption Spectrophotometry (FAAS, model: Perkin Elmar Analyst 800) in the Institute of Nuclear Science and Technology (INST) of Atomic Energy Research Establishment, Savar, Dhaka. Before each metal determinations the FAAS instrument was calibrated with four standard solutions to measure the error. Each of the four metal calibrations showed the linear calibration curve which indicates the negligible error. The readings for each target sample solutions were taken thrice and obtained data was calculated statistically by Winlab $32^{\mathrm{TM}}$ and then by SPSS (version 16.0). The levels of bioaccumulations in $H$. fossilis and L. corrianus were determined without separating organs. Sediments and water were also examined to compare bioaccumulation between living organisms and their habitats.

\section{Results and Discussion}

Sediments of Turag river showed a higher level of contamination. Mussels showed a higher $\mathrm{Cu}$ bioaccumulations as $25.57-43.53 \mathrm{mg} / \mathrm{kg}$ (average $31.9 \pm 6.21 \mathrm{mg} \mathrm{kg}$ ) than that of fish but lesser than that of sediments. In the body of $H$. fossilis it was 10.21- 17.15 $\mathrm{mg} / \mathrm{kg}$ (average: $13.27 \pm 2.47 \mathrm{mg} / \mathrm{kg}$ ), while in sediments and water it was $43.15-73.56$ $\mathrm{mg} / \mathrm{kg}$ (average: $54.95 \pm 9.21 \mathrm{mg} / \mathrm{kg}$ ) and $0-0.073 \mathrm{ppm}$ (average: $0.0253 \pm 0.023 \mathrm{ppm}$ ) respectively, which in all cases was higher than the FAO approved standard level. (FAO 2010) (Table 1 and Fig. 1). 
Table 1. Concentrations of copper, cadmium, lead and chromium in fish, mollusk, sediment and water of Turag river.

\begin{tabular}{l|c|l|l|l|l}
\hline Samples & $\mathrm{N}$ & $\begin{array}{l}\text { Copper } \\
(\mathrm{Mean} \pm \mathrm{SD})\end{array}$ & $\begin{array}{l}\text { Cadmium } \\
(\mathrm{Mean} \pm \mathrm{SD})\end{array}$ & $\begin{array}{l}\text { Lead } \\
(\mathrm{Mean} \pm \mathrm{SD})\end{array}$ & $\begin{array}{l}\text { Chromium } \\
(\mathrm{Mean} \pm \mathrm{SD})\end{array}$ \\
\hline H. fossilis & 15 & $13.2700 \pm 2.470$ & $0.2148 \pm 0.208$ & $\mathrm{BDL}^{1}$ & $1.4636 \pm 0.431$ \\
L. corrianus & 15 & $31.9011 \pm 6.212$ & $0.1826 \pm 0.025$ & $3.8656 \pm 1.041$ & $0.0367 \pm 0.039$ \\
Sediments & 15 & $54.9511 \pm 9.218$ & $0.0507 \pm 0.011$ & $34.8922 \pm 5.554$ & $5.5749 \pm 0.608$ \\
FAO standards & & 30.00 & 2.00 & 0.10 & 7.00 \\
Water & 15 & $0.0253 \pm 0.024$ & $0.0012 \pm 0.001$ & $0.1169 \pm 0.041$ & $0.2335 \pm 0.044$ \\
${ }^{2}$ MAC in & & 1.00 & 0.001 & 0.05 & 0.05 \\
Bangladesh & & & & & \\
\hline
\end{tabular}

${ }^{1} \mathrm{BDL}=$ Below the Detection Level $;{ }^{2} \mathrm{MAC}=$ Maximum Allowable Concentrations

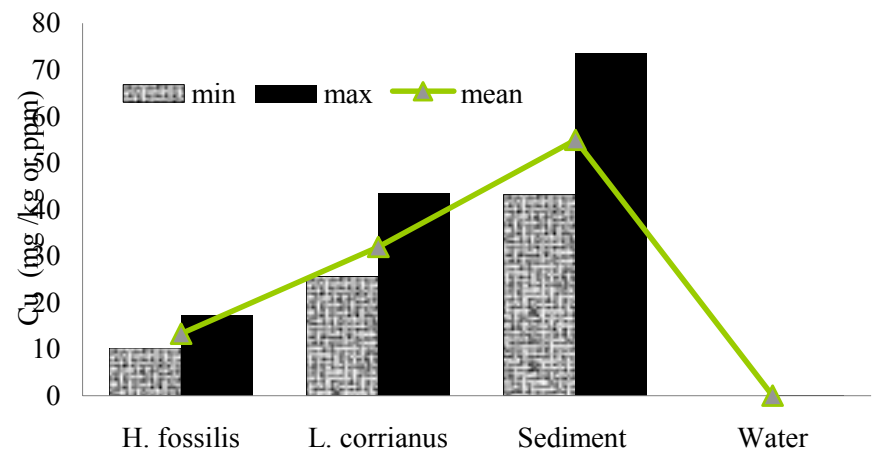

Fig. 1. Mean, minimum and maximum concentration of copper in $H$. fossilis, $L$. corrianus, sediment and water.

Similarly, the cadmium (Cd) concentrations in H. fossilis, L. corrianus and in sediments were $0.052-0.46 \mathrm{mg} / \mathrm{kg}$ (average: $0.2143 \pm 0.20 \mathrm{mg} / \mathrm{kg}$ ), $0.1235-0.220 \mathrm{mg} / \mathrm{kg}$ (average: $0.1826 \pm 0.025 \mathrm{mg} / \mathrm{kg}$ ), and $0.0325-0.722 \mathrm{mg} / \mathrm{kg}$ (average: $0.0507 \pm 0.011$ $\mathrm{mg} / \mathrm{kg}$ ) respectively (Table 1 ). This contamination level of $\mathrm{Cd}$ in water was 0.00012 $0.00233 \mathrm{ppm}$ (average: $0.0012 \pm 0.001 \mathrm{ppm}$ ). (Table 1 and Fig. 2). 


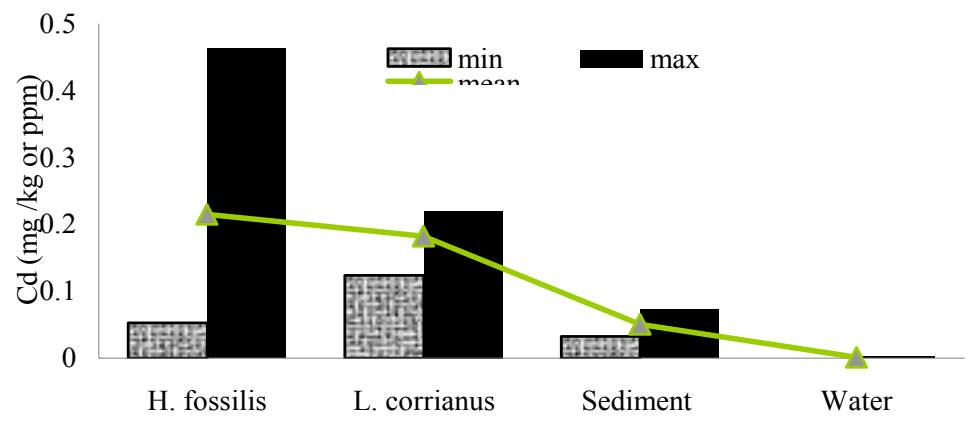

Fig. 2. Mean, minimum and maximum concentration of cadmium in $H$. fossilis, $L$. corrianus, sediment and water.

The lead concentrations were found as $0 \mathrm{mg} / \mathrm{kg}$ (below detection limit), $2.54-6.26$ $\mathrm{mg} / \mathrm{kg}$ (average: $3.86 \pm 0.01 \mathrm{mg} / \mathrm{kg}$ ), and $25.89-42.33 \mathrm{mg} / \mathrm{kg}$ (average: $34.89 \pm 5.55$ $\mathrm{mg} / \mathrm{kg}$ ) and $0.0856-0.210 \mathrm{ppm}$ (average: $0.117 \pm 0.04 \mathrm{ppm}$ ) in H. fossilis, L. corrianus, sediments and water respectively during the same study period. (Table 1 and Fig. 3 ).

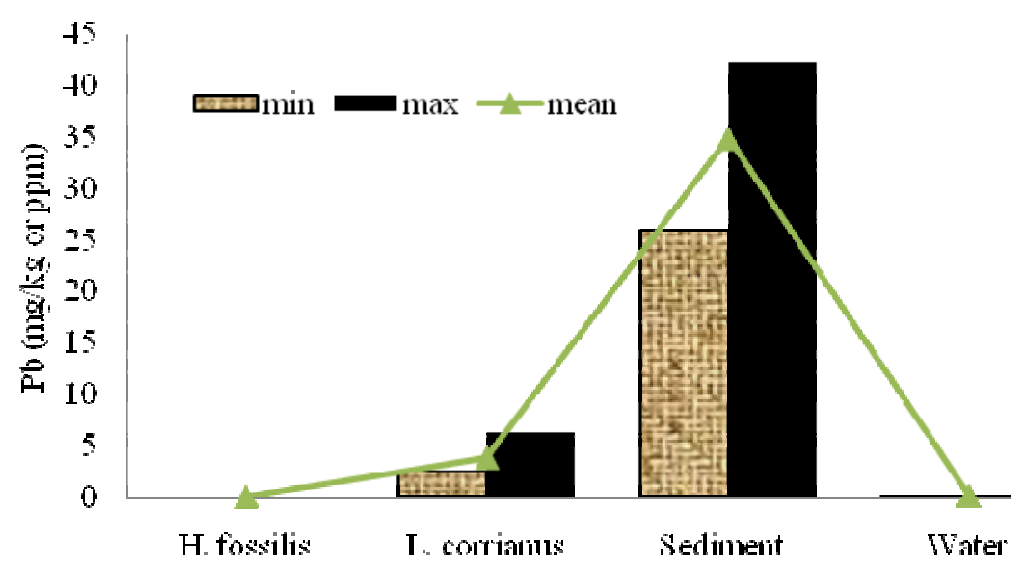

Fig. 3. Mean, minimum and maximum concentration of lead in H. fossilis, L. corrianus, sediment and water.

Again, the bioaccumulation of $\mathrm{Cr}$ in the body of $H$. fossilis, L. corrianus as well as in the sediments and water of Turag river was $0.95-2.1 \mathrm{mg} / \mathrm{kg}$ (average: $1.46 \pm 0.431 \mathrm{mg} / \mathrm{kg}$ ), 0 - $0.99 \mathrm{mg} / \mathrm{kg}$ (average: $0.03667 \pm 0.03 \mathrm{mg} / \mathrm{kg}$ ), and $4.50-6.33 \mathrm{mg} / \mathrm{kg}$ (average: $5.57 \pm$ 
$0.607 \mathrm{mg} / \mathrm{kg}$ ) and $0.165-0.291 \mathrm{ppm}$ (average: $0.233 \pm 0.04 \mathrm{ppm}$ ) respectively. (Table 1 and Fig. 4).

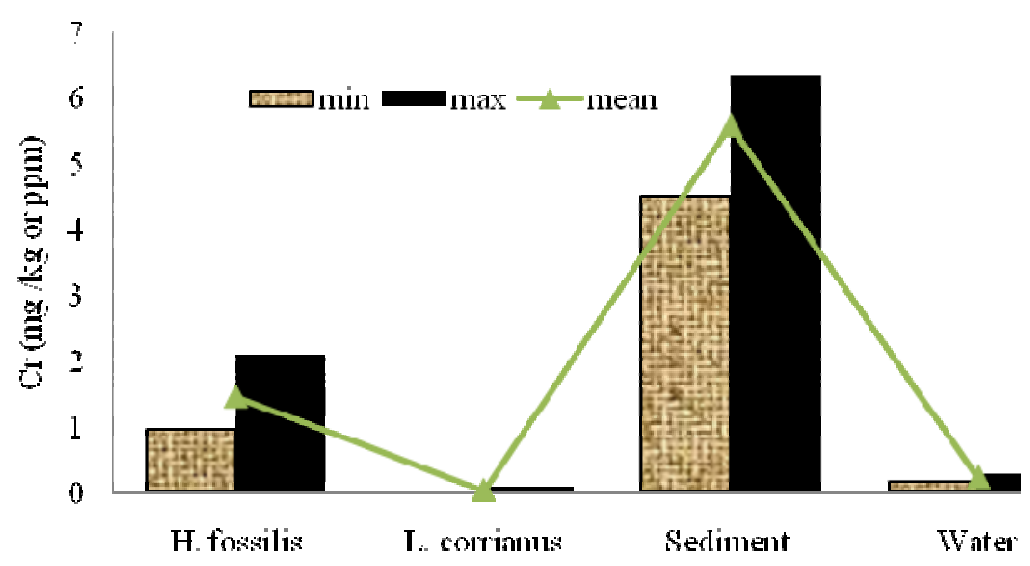

Fig. 4. Mean, minimum and maximum concentration of chromium in $H$. fossilis, $L$. corrianus, sediment and water.

Sharma and Fulekar (2009) found the concentration pattern as $\mathrm{Cu} 43.0 \mathrm{mg} / \mathrm{kg}$; $\mathrm{Cd} 4.05$ $\mathrm{mg} / \mathrm{kg}$ and $\mathrm{Pb} 2.43 \mathrm{mg} / \mathrm{kg}$ and their order of toxicity was $\mathrm{Cu}>\mathrm{Cd}>\mathrm{Pb}$ in similar kind of study on some commercial fishes of the Gulf of Cambay. In the present study, the level of heavy metals concentration in fish body were obtained as $\mathrm{Cu} 13.27 \mathrm{mg} / \mathrm{kg}$; $\mathrm{Cr} 1.46$ $\mathrm{mg} / \mathrm{kg}$; $\mathrm{Cd} 0.21 \mathrm{mg} / \mathrm{kg}$ and $\mathrm{Pb} 0.0 \mathrm{mg} / \mathrm{kg}$ (Table 1) and their order of toxicity was $\mathrm{Cu}>$ $\mathrm{Cr}>\mathrm{Cd}>\mathrm{Pb}$. Ezemonye et al. (2006) observed bioaccumulation of heavy metals in freshwater Snail (Pila ovata) from the Ikpoda river of Southern Nigeria by using AAS and obtained the mean concentration of $\mathrm{Cu} 4.56 \mathrm{mg} / \mathrm{kg}$. Whereas, in this study, the average bioaccumulation levels of different selected metals were found in mussel as $\mathrm{Cu}$ $31.9 \mathrm{mg} / \mathrm{kg}$; $\mathrm{Cr} 0.04 \mathrm{mg} / \mathrm{kg}$; $\mathrm{Cd} 0.18 \mathrm{mg} / \mathrm{kg}$ and $\mathrm{Pb} 3.8 \mathrm{mg} / \mathrm{kg}$ and in H. fossilis as $\mathrm{Cu}$ $13.27 \mathrm{mg} / \mathrm{kg}$; $\mathrm{Cr} 1.46 \mathrm{mg} / \mathrm{kg}$; $\mathrm{Cd} 0.21 \mathrm{mg} / \mathrm{kg}$ and $\mathrm{Pb} 0.0 \mathrm{mg} / \mathrm{kg}$. From this data, it is evident that the bioaccumulation rate of $\mathrm{Cu}$ and $\mathrm{Pb}$ in mussel were greater than in fish, but $\mathrm{Cr}$ and $\mathrm{Cd}$ accumulations were higher in fish (Table 1).

Ahmed et al. (2012) investigated the level of heavy metals in Ayre fish (Sperata aor) in Dhaleshwari river of Bangladesh and found the bioaccumulation levels in fish were $\mathrm{Cu}$ $31.50 \mathrm{mg} / \mathrm{kg} ; \mathrm{Pb} 18.776 \mathrm{mg} / \mathrm{kg}$; Cr $1.458 \mathrm{mg} / \mathrm{kg}$ and $\mathrm{Cd} 0.4873 \mathrm{mg} / \mathrm{kg}$ of dry weight and in sediments these levels were $\mathrm{Cu} 37.45 \mathrm{mg} / \mathrm{kg}$; $\mathrm{Cr} 27.3933 \mathrm{mg} / \mathrm{kg}$; $\mathrm{Pb} 15.7967$ $\mathrm{mg} / \mathrm{kg} ; \mathrm{Cd} 2.0830 \mathrm{mg} / \mathrm{kg}$ and in water the same were $\mathrm{Cu} 0.00 \mathrm{ppm} ; \mathrm{Pb} 0.2014 \mathrm{ppm} ; \mathrm{Cd}$ $0.0012 \mathrm{ppm}$; $\mathrm{Cr} 0.1302 \mathrm{ppm}$. Thus their suggested order of accumulations in fish $\mathrm{Cu}>$ $\mathrm{Pb}>\mathrm{Cr}>\mathrm{Cd}$, sediments $\mathrm{Cu}>\mathrm{Pb}>\mathrm{Cr}>\mathrm{Cd}$ and water $\mathrm{Cu}<\mathrm{Cd}<\mathrm{Cr}<\mathrm{Pb}$. Haque et 
al.(2003) determined the bioaccumulation of heavy metals in M. vittatus, collected from Buriganga river and reported $\mathrm{Cu} 3.595-5.139 \mathrm{mg} / \mathrm{kg} ; \mathrm{Pb} 1.031-3.3578 \mathrm{mg} / \mathrm{kg}$; $\mathrm{Cr}$ $2.04-11.79 \mathrm{mg} / \mathrm{kg}$ and $\mathrm{Cd} 0.109-1.102 \mathrm{mg} / \mathrm{kg}$. These in the present study, bioaccumulations in $H$. fossilis were $\mathrm{Cu} 13.27 \mathrm{mg} / \mathrm{kg}$ and $\mathrm{Cr} 1.46 \mathrm{mg} / \mathrm{kg}$. In the sediments of Turag river, the toxicity order was $\mathrm{Cu}>\mathrm{Pb}>\mathrm{Cr}>\mathrm{Cd}$. Against that in water samples, the levels of $\mathrm{Pb}$ and $\mathrm{Cr}$ were higher but, $\mathrm{Cd}$ and $\mathrm{Cu}$ were lower. In numerical values, these were $\mathrm{Cu} 0.0253 \mathrm{ppm}$; $\mathrm{Cr} 0.2335$ ppm ; $\mathrm{Pb} 0.1169$ ppm and $\mathrm{Cd} 0.0012$ ppm which in comparison to maximum allowable concentration levels of Bangladesh $(\mathrm{Cu} 1.0$ ppm ; $\mathrm{Cr} 0.05 \mathrm{ppm}$ and $\mathrm{Pb} 0.05 \mathrm{ppm}$ ) were more or less higher and even exceeded the MAC (GoB 1997) (Table 1).

From this study, it is apparent that the contamination levels of heavy metals in sediments and water exceeded the standard level and consequently accumulated into living organisms like fish and mollusks and even exceeded the safe levels. Thus, the Government should take immediate action to mitigate contamination of toxic heavy metals as well as other pollutants by regulating the industrial and municipal effluents discharges directly into Turag and other rivers all over Bangladesh. At the same time, the local people should be aware about harmful effect of such pollutants.

\section{Acknowledgement}

Authors are gratefully acknowledge the support of Atomic Energy Research Establishment (AERE), Savar, Dhaka to carry out the research successfully.

\section{References}

Ahmed, A.T.A., S. Mandal, D.A. Chowdhury, A.R.M. Tareq and M.M. Rahman. 2012. Bioaccumulation of some heavy metals in Ayre fish (Sperata aor Hamilton, 1822), sediment and watewr of Dhaleshwari river in dry season. Bangladesh J. Zool. 40(1):147153.

AOAC International, 2002. Official methods of analysis of AOAC International. Official Method 999.10. AOAC International, Gaithersburg, MD. $17^{\text {th }}$ Ed. Rev. 1: $307 \mathrm{pp}$.

Bendicho, C. and I. Lavilla. 2003. Ultrasound-assisted metal extractions. Encyclopedia of Separation Science. 3: 4421-4426.

Bhattacharya, A.K., S.N. Mandal and S.K. Das, 2007. Bioaccumulation of zinc, copper and lead in upper stretch of Gangetic West Bengal. Trends Applied Sci. Res. 2: 492-499.

Davies, O.A., M.E. Allison and H.S. Uye. 2006. Bioaccumulation of heavy metals in water, sediment and periwinkle (Tympanotonus fuscatus var radula) from the Elechi Creek, Niger Delta. Africal J. Biotechnology. 5 (10): 968-973.

Ezemonye, L., V. Enobakhare and I. Ilechie. 2006. Bioaccumulation of heavy metals (Cu, $\mathrm{Zn}, \mathrm{Fe})$ in freshwater snail (Pila ovata Oliver, 1804) from Ikpoba river of Southern Nigeria. $J$. Aquatic Sci. 21 (1): 23-28.

FAO. 2010. Trace metals in environments. http://www.fao.org/trace metals.html.

GoB (Government of Bangladesh) 1997. Environmental Conservation Regulation 1997. Government of People's Republic of Bangladesh. 
Haque, W., A.T.A. Ahmed, S.A. Tarafdar, S.Akhter and S.B. Quraishi. 2003. Trace elements in two small fishes, Puntius sophore (Hamilton) and Mystus vittetus (Bloch) from Buriganga river, Balu river and Ichamoti beel. Bangladesh J. Zool. 31 (2): 247-251.

Kebede, A. and T. Wondimu. 2004. Distribution of trace elements in muscle and organs of Tilapia, Oreochromis niloticus, from Lakes Awassa and Ziway, Ethiopia. Bulletine of Chemical Society of Ethiopia. 18 (2): 119-130.

Lenntech. 2010. Heavy-metals. http://www.lenntech.com/processes/heavymetals/heavy-metals. $\mathrm{htm}$.

Sharma, J. and M.H. Fulekar. 2009. Potential of Citrobacter freundii for bioaccumulation of heavy metal - copper. Biology and Medicine. 1 (3): 7-14.

(Received revised manuscript on 19 May 2013) 